\title{
Pengaruh kualitas pelayanan dan harga terhadap kepuasan pelanggan jasa transportasi Gojek di Kota Jambi
}

\author{
Rizkon Ariyandi; Dahmiri*; Novita Sari \\ Program Studi Manajemen Fakultas Ekonomi dan Bisnis Universitas Jambi \\ *E-mail korespodensi: dahmiri@unja.ac.id
}

\begin{abstract}
One of the transportation service companies that is developing in the city of Jambi is Gojek. Go-Jek is the pioneer of mobile application-based motorcycle taxi services through its Go-Ride service. The increasing number of online motorcycle taxis has an impact on the tighter competition. The factors causing this are price competition and the many alternative choices for online motorcycle taxi services. The purpose of this study was to determine the effect of service quality and price simultaneously and partially on customer satisfaction on GoJek transportation services in Jambi City. The approach used in this research is a quantitative approach. The sampling technique used was through interviews, observations and questionnaires. The data analysis technique in this study is multiple linear regression with the help of SPSS version 25.0 software. The results of this study are: (1) Service quality does not have a significant effect on customer satisfaction of Gojek online transportation users in Jambi city and this variable has a positive influence on customer satisfaction. (2) Price has a significant effect on customer satisfaction of Gojek online transportation users in Jambi city and this variable has a positive influence on customer satisfaction. (3) Service quality and price perception together have a significant influence on customer satisfaction of Gojek online transportation users in the city of Jambi and this variable has a positive influence on customer satisfaction.
\end{abstract}

\section{Keywords: customer satisfaction, service quality, price}

\begin{abstract}
Abstrak
Salah satu perusahaan jasa transportasi yang sedang berkembang di kota Jambi adalah Gojek. GoJek menjadi pionir layanan ojek berbasis aplikasi mobile melalui layanan GoRide-nya. Semakin banyaknya ojek online berdampak pada semakin ketatnya persaingan. Faktor yang menjadi penyebab terjadinya hal tersebut yakni adanya persaingan harga dan banyaknya alternatif pilihan jasa ojek online. Tujuan penelitian ini adalah untuk mengetahui pengaruh kualitas pelayanan dan harga secara simultan dan parsial terhadap kepuasan pelanggan pada jasa transportasi GoJek di Kota Jambi. Pendekatan yang digunakan dalam penelitian ini adalah pendekatan kuantitatif. Teknik pengambilan sampel yang digunakan adalah melalui wawancara, observasi dan kuesioner. Teknik analisis data dalam penelitian ini adalah regresi linear berganda dengan bantuan software SPSS versi 25.0. Hasil dari penelitian ini adalah: (1) Kualitas pelayanan tidak memiliki pengaruh signifikan terhadap kepuasan pelanggan pengguna transportasi online Gojek di kota Jambi dan variabel ini memiliki arah pengaruh yang positif terhadap kepuasan pelanggan. (2) Harga memiliki pengaruh signifikan terhadap kepuasan pelanggan pengguna transportasi online Gojek di kota Jambi dan variabel ini memiliki arah pengaruh yang positif terhadap kepuasan pelanggan. (3) Kualitas pelayanan dan persepsi harga secara bersama-sama memiliki pengaruh signifikan terhadap kepuasan pelanggan pengguna transportasi online Gojek di kota Jambi dan variabel ini memiliki arah pengaruh yang positif terhadap kepuasan pelanggan.
\end{abstract}

Kata kunci: kepuasan pelanggan, kualitas pelayanan, harga. 


\section{PENDAHULUAN}

Pada era globalisasi persaingan bisnis yang dihadapi perusahaan- perusahaan saat ini semakin ketat, sehingga menuntut manajemen perusahaan untuk lebih cermat dalam menentukan strategi bersaingnya, agar dapat memenangkan dalam persaingan yang dihadapinya. Manajemen perusahaan dituntut untuk dapat mendesain dan mengimplementasikan strategi pemasaran yang mampu menciptakan, mempertahankan, dan meningkatkan kepuasan pelanggan. Bisnis jasa saat ini semakin beragam dalam rangka memenuhi kebutuhan hidup masyarakat. Pentingnya sektor jasa ini disikapi dengan pertumbuhan bisnis jasa yang semakin pesat. Salah satu bisnis dalam sektor jasa yang semakin berkembang pesat adalah jasa transportasi (Mar'ati \& Sudarwanto, 2014).

Di Indonesia banyak dijumpai sepeda motor juga melakukan fungsi sebagai kendaraan umum yaitu mengangkut orang/barang dan memungut biaya yang disepakati, moda transportasi jenis ini dikenal dengan nama Gojek. Modal transportasi ojek sudah dikenal terutama di Jakarta dan daerah lain sejak bertahun-tahun lalu, namum saat ini ojek sudah banyak digunakan terutama di kota-kota besar yaitu Jabodetabek, Bandung, Surabaya, Bali, dan Makasar (Mar'ati \& Sudarwanto,2014).

Salah satu perusahaan jasa transportasi yang sedang berkembang di kota Jambi adalah Gojek. PT. Gojek Indonesia didirikan pada tahun 2011 oleh Nadiem Makarim dan Michaelangelo Moran. Perusahaan ini bergerak di bidang jasa layanan transportasi sebagai perantara yang menghubungkan antara para pengendara ojek dengan pelanggan.Pada Januari 2015, perusahaan meluncurkan aplikasi mobile Gojek berbasis location-based search untuk telepon genggam berbasis android dan IOS (apple).Melalui aplikasi ini, pengendara ojek dapat melihat orderyang masuk dan lokasi pemesannya untuk ditanggapi, dan pelanggan dapat memantau posisi pengendara ojek yang menanggapi order.

Penelitian kualitas pelayanan dilakukan oleh Mar'ati (2016) tentang "Pengaruh Kualitas pelayanan dan Harga terhadap Kepuasan Pelanggan Jasa Transportasi Ojek Online (Studi pada Konsumen Gojek di Surabaya)".Hasil penelitian menunjukkan bahwa kualitas pelayanan berpengaruh secara signifikan terhadap kepuasan pelanggan.Namun penelitian yang dilakukan Yesenia (2014) tentang "Pengaruh Kualitas pelayanan dan Produk terhadap Kepuasan serta Loyalitas Pelanggan Kentucky Fried Chicken di Tangerang Selatan" menunjukkan kualitas pelayanan tidak berpengaruh terhadap kepuasan pelanggan.

Harga jual pada hakekatnya merupakan tawaran kepada para konsumen. Apabila konsumen menerima harga tersebut pada saat akan melakukan pembelian, maka produk tersebut akan laku, sebaliknya bila konsumen menolaknya pada saat akan melakukan pembelian, maka diperlukan peninjauan kembali harga jualnya. Ada kemungkinan bahwa konsumen memiliki ketidaksesuaian setelah melakukan pembelian karena mungkin harganya dianggap terlalu mahal atau karena tidak sesuai dengan keinginan dan gambaran sebelumnya (Kusumastuti, 2011).

Hasil riset yang dilakukan oleh Wahyuno (2013) memperkuat teori yang dikemukakan di atas tentang "Pengaruh kualitas pelayanan dan harga terhadap kepuasan pelanggan pengguna jasa Hotel Anugerah Glagah Indah Temon Kulon Progo Yogyakarta". Hasil penelitian menunjukkan bahwa kualitas pelayanan dan harga berpengaruh positif dan signifikan secara parsial dan simultan terhadap kepuasan pelanggan di Hotel Anugerah Glagah Indah. Namun demikian terdapat hasil penelitian yang berbeda dari Laila, dkk (2012) melakukan penelitian tentang "Pengaruh Kualitas Pelayanan, Harga dan Nilai Pelanggan terhadap Kepuasan Pelanggan Pengguna Jasa Servis Bengkel AHAS 0002 Semarang Honda Center", Hasil penelitian menunjukkan bahwa harga tidak berpengaruh terhadap kepuasan anggota.

Di Kota Jambi saat ini ter//sedia banyak penyedia jasa transportasi ojek online yang tidak memiliki aturan tertentu, baik secara tarif, standar pelayanan,jam 
operasional,dll. Sehingga untuk mengubah pandangan tersebut di mata pengguna jasa sebagai angkutan umum yang tidak resmi, maka PT. Gojek Indonesia yang telah berdiri sejak tahun 2010 menyediakan jasa transportasi ojek online yang berbasis aplikasi dengan merk GoJek yang dilengkapi dengan fasilitas, yaitu sepeda motor dengan minimal keluaran tahun 2000, aplikasi yang terdapat nama, nomor telfon dan GPS untuk melacak keberadaan para drivernya, jaket, jas hujan, helm, asuransi, layanan order melalui aplikasi yang dapat digunakan dengan mudah, dan terdapat layanan pengaduan dan pada akhir pelayanan pelanggan dapat memberikan review dan rating untuk driver tentang pelayanan yang sudah didapatkannya sehingga perusahaan dapat mengetahui pelayanan yang telah di dapatkan oleh konsumen dan perusahaan akan terus memperbaiki standar pelayanannya.

Dari survey awal yang dilakukan terhadap pelanggan Go-Jek di Kota Jambi diperoleh informasi bahwa layanan Gojek cukup banyak digunakan oleh berbagai kalangan di kota Jambi. Namun, Gojek bukanlah satu-satunya penyedia layanan ojek online di kota Jambi akan tetapi terdapat dua pesaing penyedia layanan ojek online lainnya, yaitu Grab dan Maxim. Hal ini tentu akan membuat pelanggan membandingkan kualitas pelayanan dari masing-masing penyedia layanan ojek online tersebut. Selain kualitas pelayanan, persepsi harga juga menjadi pertimbangan bagi pelanggan dalam memilih penyedia layanan ojek online.

\section{TINJAUAN PUSTAKA}

Kotler (2010) menjelaskan bahwa "kepuasan pelanggan adalah perasaan senang atau kecewa yang timbul karena membandingkan kinerja yang dipersepsikan produk (atau hasil) terhadap ekspektasi mereka".

Kualitas layanan merupakan keseluruhan berbagai ciri dan karakteristik dari suatu produk atau jasa dalam hal kemampuan untuk memenuhi berbagai kebutuhan yang telah ditentukan atau yang bersifat laten. Berbagai karakteristik jasa di atas, dianggap penting dalam menentukan kualitas jasa dan layanan.Oleh karena itu, Zeithaml, V. A., Parasuraman, A., \& Berry, L. L. (1990) menyarankan tiga tema pokok dalam menentukan kualitas jasa, yaitu sebagai berikut.

Bagi konsumen, kualitas jasa adalah lebih sulit diukur dibandingkan dengan kualitasbarang.

Kualitas jasa adalah hasil perbandingan antara apa yang diharapkan konsumen dengan kinerja yangditerima.

Evaluasi terhadap jasa bukan hanya pada hasil jasa semata, melainkan juga mencakup evaluasi terhadap proses pengirimnya (deliveryprocess).

Kualitas pelayanan yang baik dapat menjadi keunggulan bersaing bagi perusahaan jasa seperti yang dikemukakan oleh Zeithaml, V. A., Parasuraman, A., \& Berry, L. L. (1990) bahwa: "A second factor behind service quality's rising prominence is that superior quality is proving to be winning competitive strategy. They use service to be different, they useserviceto increase productivity, they use service to earn the cutomer's loyalty, they use service to fan positive word-of-mouth advertising, they use service to seek same shelter from price competititon.

\section{Dimensi kualitas pelayanan}

Zeithaml (2006) mengemukakan lima dimensi dalam menentukan kualitas jasa, yaitu sebagai berikut: a).Reliability, yaitu kemampuan untuk memberikan pelayanan yang sesuai dengan janji yangditawarkan. b).Responsiveness, yaitu respon atau kesigapan karyawan dalam membantu pelanggan dan memberikan pelayanan yang cepat dan tanggap, yang meliputi: kesigapan karyawan dalam melayani pelanggan, kecepatan karyawan dalam menangani traansaksi, dan penanganan keluhanpelanggan. 
c).Assurance, meliputi kemampuan karyawan atas pengetahuan terhadap produk secara tepat, kualitas keramahtamahan, perhatian dan kesopanan dalam memberi pelayanan, ketrampilan dalam memberikan informasi, ketrampilan dalam memberikan keamanan di dalam memanfaatkan jasa yang ditawarkan, dan kemampuan dalam menanamkan kepercayaan pelanggan terhadap perusahaan. Dimensi kepastian atau jaminan ini merupakan gabungan daridimensi: d).Emphaty, yaitu perhatian secara individual yang diberikan perusahaan kepada pelanggan seperti kemudahan untuk menghubungi perusahaan, kemampuan karyawan untuk berkomunikasi dengan pelanggan, dan usaha perusahaan untuk memahami keinginan dan kebutuhan pelanggannya. Dimensi emphaty ini merupakan penggabungan dari tiga dimensi, yaitu sebagai berikut. e).Tangibles, meliputi penampilan fasilitas fisik seperti gedung dan ruangan, tersedianya tempat parkir, kebersihan, kerapihan dan kenyamanan ruangan, kelengkapan peralatan komunikasi, dan penampilan karyawan.

Kualitas layanan dalam penelitian ini menggunakan pendekatan objektif yang menekankan pada pandangan kualitas secara internal, melalui pendekatan produksi dan penawaran, mengadaptasi pada pandangan yang bersifat spesifikasi yang belum mapan, meniadakan kesalahan transaksi, rendahnya biaya dan penghindaran terhadap penyimpangan dari seperangkat standar, serta sesuai dengan aktifitas yang distandarkan. Kualitas pelayanan dalam penelitian ini diukur dengan menggunakan 5 indikator dari Zeithaml (2006) yang meliputi: tangibles, reliability, responsiveness, assurance, empathy. Kotler (2010) mengatakan bahwa harga (price) adalah sejumlah uang yang harus dibayar oleh pelanggan untuk memperoleh produk. Variabel ini merupakan hal yang dapat dikendalikan dan menentukan diterima atau tidaknya suatu produk oleh konsumen. Harga sematamata tergantung pada kebijakan perusahaan tetapi tentu saja dengan mempertimbangkan berbagai hal. Murah atau mahalnya harga suatu produk sangat relatif sifatnya.

\section{METODE}

\section{Jenis dan sumber data}

Data primer didapatkan langsung dari sampel penelitian yaitu konsumen Gojek di kota Jambi.Data primer yang diambil dalam penelitian ini meliputi variabel yang diteliti yaitu kualitas pelayanan harga dan kepuasan pelanggan. Dalam Penelitian ini yang menjadi sumber data sekunder adalah literatur, jurnal, serta situs di internet yang berkenaan dengan penelitian yang dilakukan.

\section{Populasi dan sampel}

Penentuan jumlah sampel responden didasarkan pada pernyataan Supranto (2001), yang menyatakan bahwa ukuran sampel yang baik dapat ditentukan dengan cara, jumlah pernyataan dalam kuesioner dikali 5 sampai 10. Jadi dalam penentuan jumlah sampel pada penelitian ini, perhitungannya adalah sebagai berikut:

$\mathrm{n}=5 \times$ Jumlah pernyataan

$\mathrm{n}=5 \times 30$

$\mathrm{n}=150$

Dimana: $\mathrm{n}=$ Jumlah sampel

Berdasarkan perhitungan diatas, maka Jumlah sampel yang digunakan sebagai sumber data dalam penelitian adalah 150 responden.

\section{Teknik pengumpulan data}

Pengumpulan data dalam penelitian ini akan menggunakan teknik wawancara, observasi dan penyebaran kuesioner. 


\section{Variabel penelitian dan definisi operasional variabel}

Variabel dependent atau variabel terikat, adalah variabel yang menjadi pusat perhatian peneliti karena variabel ini yang dipengaruhi atau yang menjadi akibat dari adanya variabel independen atau variabel bebas (Ferdinand, A, 2006). Variabel dependen yang digunakan dalam penelitian ini adalah kepuasan pelanggan yang dilambangkan dengan Y.

Variabel independent atau variabel bebas, adalah variabel yang mempengaruhi variabel dependen, baik yang pengaruhnya positif maupun yang pengaruhnya negatif (Ferdinand, A, 2006). Variabel independen yang digunakan dalam penelitian ini adalah kualitas pelayanan yang dilambangkan dengan $\mathrm{X}_{1}$ dan harga yang dilambangkan dengan $\mathrm{X}_{2}$.

\section{Uji kualitas data}

Untuk menguji kualitas data maka dilakukan uji validitas dan uji reliabilitas. Uji validitas Uji validitas instrumen dilakukan untuk menunjukan keabsahan dari instrumen yang akan dipakai pada penelitian sedangkan uji reliabilitasu untuk mengetahui ketetapan suatu instrumen (alat ukur) didalam mengukur gejala yang sama walaupun dalam waktu yang berbeda Arikunto, 2006; Sugiyono, 2014) .

\section{Uji hipotesis}

Untuk menguji hipotesis dilakukan uji Koefisien determinasi $\left(\mathrm{R}^{2}\right)$ digunakan untuk mengetahui seberapa jauh variasi variabel independen dapat menerangkan dengan baik variasi variabel dependen. Uji t dilakukan untuk melihat signifikansi dari pengaruh variabel independen secara individual terhadap variabel dependen dengan menganggap variabel independen lainnya adalah konstan. Uji F dilakukan untuk mengetahui apakah semua variable bebas secara simultas mempengaruhi variable terikat.

\section{HASIL DAN PEMBAHASAN}

\section{Hasil uji validitas}

Berdasarkan hasil analisis validitas masing-masing butir instrument dengan membandingkan $r_{\text {tabel }}$ (dimana $n=100$ memiliki $r_{\text {tabel }}$ sebesar 0.160). Berdasarkan hasil uji validitas pada variabel kualitas pelayanan, persepsi harga dan kepuasan pelanggan diketahui angka $r$ hitung untuk item 1 sampai dengan item 27berkisar 0.202 sampai dengan 0.458. Hasil tersebut menunjukkan bahwa Kuesioner nomor 1 sampai dengan nomor 27 adalah valid karena nilai $r$ hitungnya lebih besar dari $r$ tabel yaitu 0.160 .

\section{Uji reliabilitas}

Berdasarkan hasil pengujian realibilitas diketahui angka Cronbach's Alpha adalah sebesar 0.724. Angka tersebut lebih besar dari nilai minimal Cronbach'sAlpha yaitu sebesar 0.60. Oleh karena itu, dapat disimpulkan bahwa instrument penelitian atau data jawaban responden atas kuesioner yang digunakan untuk mengukur variabel kualitas pelayanan, persepsi harga dan kepuasan pelanggandapat dikatakan handal / dapat dipercaya.

\section{Uji normalitas}

Hhasil uji normalitas secara statistik dengan metode One Sample Kolmogorov Smirnov. Untuk menentukan normalitas dari data tersebut cukup dengan membaca nilai signifikansinya (Asymp.Sig. 2-tailed). Diketahui bahwa nilai signifikansi Asymp.Sig.(2-tailed) sebesar 0.200 lebih besar dari 0.05. Maka sesuai dengan dasar pengambilan keputusan dalam uji normalitas One Sample Kolmogorov Smirnov diatas, dapat disimpulkan bahwa data berdistribusi normal. 


\section{Hasil uji hipotesis}

\section{Koefisien determinasi}

Uji ini dilakukan untuk mengukur tingkat kemampuan variabel independen, yaitu kualitas pelayanan dan persepsi harga dalam menjelaskan variabel dependen yaitu kepuasan pelanggan. Hasil uji koefisien Adjusted R Square dalam penelitian ini disajikan dalam table dengan rincian sebagai berikut.

Tabel 1 Koefisien Determinasi

\section{Model Summary}

\begin{tabular}{|c|c|c|c|c|}
\hline Model & $\mathrm{R}$ & R Square & $\begin{array}{l}\text { Adjusted R } \\
\text { Square }\end{array}$ & $\begin{array}{l}\text { Std. Error of } \\
\text { the Estimate }\end{array}$ \\
\hline 1 & $0,624^{\mathrm{a}}$ & 0,390 & 0,381 & 2,17349 \\
\hline
\end{tabular}

a. Predictors: (Constant), Persepsi Harga, Kualitas Pelayanan

Sumber: Data diolah, 2020

Berdasarkan analisis data pada Tabel 1 menunjukkan bahwa nilai koefisien Adjusted R Square adalah sebesar 0,381 Hal ini berarti $38.1 \%$ variabel kepuasan pelanggan dapat dijelaskan oleh variable kualitas pelayanan dan persepsi harga. Sedangkan sisanya $(100 \%-38.1 \%=61.9 \%)$ dijelaskan oleh faktor-faktor lain yang tidak dimasukkan dalam penelitian ini.

\section{Uji Statistik F}

Uji f dilakukan dengan tujuan menguji apakah semua variabel independen yaitu kualitas pelayanan dan persepsi harga yang dimasukkan dalam model mempunyai pengaruh secara bersama-sama terhadap variabel dependen yaitu kepuasan pelanggan dengan hasil uji sebagai berikut:

Tabel 2. Hasil uji F

\begin{tabular}{llrrrrr}
\hline Model & \multicolumn{1}{c}{$\begin{array}{c}\text { Sum of } \\
\text { Squares }\end{array}$} & df & Mean Square & F & \multicolumn{1}{c}{ Sig. } \\
\hline 1 & Regression & 443,561 & 2 & 221,781 & 46,947 & $0,000^{\mathrm{b}}$ \\
Residual & 694,439 & 147 & 4,724 & & \\
Total & 1138,000 & 149 & & &
\end{tabular}

a. Dependent variable: kepuasan pelanggan

b. Predictors: (constant), persepsi harga, kualitas pelayanan

Sumber: Data diolah, 2020

Berdasarkan Tabel 1 yang menunjukkan hasil uji $\mathrm{F}$ dengan signifikansi sebesar 0,000 yang memiliki nilai lebih kecil dari $\alpha=0.05$ (5\%). Artinya bahwa variabel kualitas pelayanan dan persepsi harga secara bersama-sama berpengaruh secara signifikansi terhadap variabelkepuasan pelanggan.

\section{Uji statistik $\mathbf{t}$}

Uji t bertujuan untuk menguji seberapa jauh pengaruh satu variabel independen secara individual yaitu harga, desain produk dan citra merek dalam menerangkan variasi variabel dependen, yaitu keputusan pembelian dengan hasil uji sebagai berikut : 
Tabel 3. Hasil uji t

\begin{tabular}{|c|c|c|c|c|c|c|}
\hline \multicolumn{7}{|c|}{ Coefficients $^{\mathrm{a}}$} \\
\hline & \multirow[t]{2}{*}{ Model } & \multicolumn{2}{|c|}{$\begin{array}{l}\text { Unstandardized } \\
\text { Coefficients }\end{array}$} & \multirow{2}{*}{$\begin{array}{c}\begin{array}{c}\text { Standardized } \\
\text { Coefficients }\end{array} \\
\text { Beta }\end{array}$} & \multirow[t]{2}{*}{$\mathbf{t}$} & \multirow[t]{2}{*}{ Sig. } \\
\hline & & B & Std. Error & & & \\
\hline \multirow[t]{4}{*}{1} & (Constant) & 10,134 & 2,203 & & 4,601 & , 00 \\
\hline & Kualitas &, 085 &, 076 & ,092 & 1,112 & 268 \\
\hline & Pelayanan & & & & & \\
\hline & Persepsi Harga & 459 & 067 &, 563 & 6,827 & 000 \\
\hline
\end{tabular}

a. Dependent variable: kepuasan pelanggan

Sumber: Data diolah, 2020

\section{Pengaruh kualitas pelayanan terhadap kepuasan pelanggan}

Berdasarkan hasil pengujian pada Tabel 5.11 yang dilakukan diperoleh angka nilai t hitung variabel X1 sebesar 1.112 dengan tingkat signifikansi sebesar 0.268 , dikarenakan angka taraf signifikansi lebih kecil dari $\alpha=0.05$ (5\%) maka dapat disimpulkan bahwa kualitas pelayanan tidak berpengaruh signifikan terhadap kepuasan pelanggan. Berdasarkan dari penjelasan tersebut oleh karena itu $\mathrm{H}_{0}$ diterima dan $\mathrm{H}_{1}$ ditolak, artinya kualitas pelayanan tidak berpengaruh signifikan terhadap kepuasan pelanggan.

\section{Pengaruh persepsi harga terhadap kepuasan pelanggan}

Berdasarkan hasil pengujian pada Tabel 5.11 yang dilakukan diperoleh angka nilai t hitung variabel X2 sebesar 6.827 dengan tingkat signifikansi sebesar 0.000, dikarenakan angka taraf signifikansi lebih kecil dari $\alpha=0.05$ (5\%) maka dapat disimpulkan bahwa persepsi harga berpengaruh signifikan terhadap kepuasan pelanggan. Berdasarkan dari penjelasan tersebut oleh karena itu $\mathrm{H}_{0}$ ditolak dan $\mathrm{H}_{1}$ diterima, artinya persepsi harga berpengaruh terhadap kepuasan pelanggan.

\section{Pengaruh kualitas pelayanan dan persepsi hargaterhadap kepuasan pelanggan}

Berdasarkan hasil pengujian pada Tabel 5.10 diperoleh hasiluji f dengan tingkat signifikansi sebesar 0.000, dikarenakan angka taraf signifikansi lebih kecil dari $\alpha=0.05$ (5\%) maka dapat disimpulkan bahwa variabel-variabel independen yaitu kualitas pelayanan dan persepsi harga secara bersama-sama berpengaruh secara signifikansi terhadap variabel dependen yaitu kepuasan pelanggan. Berdasarkan dari penjelasan tersebut oleh karena itu $\mathrm{H}_{0}$ ditolak dan $\mathrm{H}_{1}$ diterima, artinya kualitas pelayanan dan persepsi harga berpengaruh secara simultan terhadap variabel dependen yaitu kepuasan pelanggan.

\section{Pengaruh kualitas pelayanan terhadap kepuasan pelanggan}

Hasil penelitian menunjukan bahwa variabel kualitas pelayanan di peroleh nilai $\mathrm{t}$ hitung sebesar 1.112 dengan signifikasi sebesar 0,268 lebih besar dari 0.05, dalam koefesien regresi mempunyai nilai positif sebesar 0.085 , maka hasil penelitian menolak hipotesis pertama yang menyatakan bahwa "kualitas pelayanan berpengaruh signifikan terhadap kepuasan pelanggan pengguna jasa transportasi ojek online Gojek di Kota Jambi”. Hasil penelitian ini menunjukkan bahwa kepuasan pelanggan pengguna transportasi online Gojek di kota Jambi tidak mengacu pada kualitas pelayanan.

Hasil penelitian berbanding terbalik terhadap penelitian sebelumnya yang dilakukan oleh Mar'ati (2016) tentang "Pengaruh Kualitas Layanan dan Harga Terhadap Kepuasan Terhadap Pelanggan Jasa Transportasi Ojek Online (Studi Pada Konsumen Gojek di Surabaya)". Hasil penelitian menunjukan kualitas layanan berpengaruh secara 
positif dan signifikan terhadap kepuasan pelanggan.

Kualitas pelayanan yang baik dapat menjadi keunggulan bersaing bagi perusahaan jasa. Kualitas pelayanan juga merupakan kunci untuk mencapai kesuksesan. Baik tidaknya kualitas pelayanan barang atau jasatergantung pada kemampuan produsen dalam memenuhi harapan konsumen secara konsisten. Kualitas pelayanan dikatakan memuaskan jika layanan yang dirasakan sama atau melebihi pelayanan yang diharapkan. Pelayanan yang seperti inilah yang dipersepsikan sebagai pelayanan berkualitas dan memuaskan.Harapan konsumen tersebut tercermin pada pelayanan yang baik, ramah tamah, sopan santun, ketepatan waktu, dan kecepatan menjadi nilai penting yang diharapkan oleh para konsumen. Oleh karena itu, kualitas pelayanan harus menjadi fokus utama perhatian perusahaan karena dapat menciptakan kepuasan pelanggan.

\section{Pengaruh harga terhadap kepuasan pelanggan}

Hasil penelitian menunjukan bahwa variabel harga di peroleh nilai $\mathrm{t}$ hitung sebesar 6.827 dengan nilai signifikansi sebesar 0.000 dan koefisien regresi mempunyai nilai positif sebesar 0.459 , maka hipotesis yang menyatakan bahwa "Persepsi harga berpengaruh signifikanterhadap kepuasan pelanggan pengguna jasa transportasi ojek online Gojek di kota Surabaya". Hasil penelitian ini menunjukkan bahwa persepsi harga memiliki dampak terhadap kepuasan pelanggan pada pengguna transportasi online Gojek di kota Jambi.

Hasil penelitian ini mendukung penelitian sebelumnya yang dilakukan oleh Wahyuno (2013) melakukan penelitian tentang "pengaruh kualitas pelayanan dan harga terhadap kepuasan pelanggan pengguna jasa Hotel Anungrah Glagah Indah Temon Kulon Progo Yogyakarta". Hasil penelitian menunjukan bahwa harga bepengaruh positif dan signifikan terhadap kepuasan pelanggan di Hotel Anugrah Glagah Indah.

Faktor kedua yang mempengaruhi kepuasan pelanggan adalah persepsi harga. Menurut Kotler (2010) harga adalah jumlah uang (kemungkinan di timbang beberapa barang) yang di butuhkan untuk memperoleh beberapa kombinasi sebuah produk dan pelayanan yang menyertainya. Harga merupakan hal yang dapat dikendalikan dan menentukan di terima atau tidaknya suatu produk oleh konsumen. Harga semata-mata tergantung pada kebijakan perusahaan tetapi tentu saja dengan mempertimbangkan berbagai hal. Murah atau mahalnya harga suatu produk sangat relative sifatnya. Perusahaan harus selalu memonitor harga yang di tetapkan oleh para pesaing, agar harga yang di tentukan oleh perusahaan tersebut tidak terlalu tinggi atau sebaliknya.

Pada tingkat harga tertentu, jika manfaat yang di rasakan meningkat, maka nilainya akan meningkat pula. Apabila nilai yang di rasakan pelanggan semakin tinggi, maka akan menciptakan kepuasan pelanggan yang maksimal (Tjiptono, 2008). Indikator penilaian harga dapat dilihat dari kesesuaian antara suatu pengorbanan dari konsumen terhadap nilai yang diterimanya setelah melakukan pembelian, dan dari situlah konsumen akan mempersepsi dari produk atau jasa tersebut. Persepsi positif merupakan hasil dari rasa puas akan suatu pembelian yang dilakukannya dan persepsi negatif merupakan bentuk ketidakpuasan konsumen atas produk atau jasa yang dibelinya.

\section{Pengaruh kualitas pelayanan dan harga terhadap kepuasan pelanggan}

Dari hasil pengujian di peroleh nilai $\mathrm{F}$ hitung sebesar 46,947 dengan signifikasi sebesar 0,000. Oleh karena nilai signifikasi lebih kecil dari 0.05, maka dapat di simpulkan bahwa penelitian ini berhasil membuktikan hipotesis keempat yang menyatakan "Terdapat pengaruh kualitas pelayanan, deal harga secara bersama-sama terhadap kepuasan pelanggan pengguna jasa transportasi ojek online Gojek di Kota Jambi".

Hasil penelitian ini relevan dengan penelitian Mar'ati (2016) tentang "Pengaruh Kualitas Layanan dan Harga Terhadap Kepuasan Pelanggan Jasa Transportasi Ojek 
Online (Studi Pada Konsumen Gojek di Surabaya)".Hasil penelitian menunjukan bahwa kualitas pelayanan dan harga berpengaruh terhadap kepuasan pelanggan. Penelitian ini juga sejalan dengan hasil penelitian Dahmiri, D. (2016) yang menyimpulkan bahwa Kualitas Pelayanan mempengaruhi Kepuasan.

Kualitas pelayanan dan harga merupakan hal penting yang dapat mempengaruhi kepuasan pelanggan. Zeithaml, V. A., Parasuraman, A., \& Berry, L. L. (1990) menyatakan bahwa kualitas pelayanan yang tinggi menghasilkan kepuasan pelanggan yang tinggi pula.Apabila pelayanan yang diterima atau dirasakan pelanggan sesuai atau bahkan melebihi harapan pelanggan,maka pelayanan tersebut dianggap berkualitas dan memuaskan.Faktor kedua yang mepengaruhi kepuasan pelanggan adalah persepsi harga. Jika harga yang ditetapkan oleh sebuah perusahaan tidak sesuai dengan manfaat produk maka hal itu dapat menurunkan tingkat kepuasan pelanggan, dan sebaliknya jika harga yang ditetapkan oleh sebuah perusahaan sesuai dengan manfaat yang diterima maka akan meningkatkan kepuasan pelanggan.

Menurut Buttle (2007) kepuasan pelanggan membawa dampak yang besar bagi perusahaan. Dengan memertahankan dan memuaskan pelanggan saat ini jauh lebih mudah dibandingkan terus-menerus berupaya menarik atau memprospek pelanggan baru, biaya memertahankan pelanggan lebih murah dibandingkan biaya mencari pelanggan baru. Pelanggan yang puas dapat menjadikan hubungan antara perusahaan dan pelanggan menjadi harmonis, memberikan dasar yang baik bagi pembelian ulang dan terciptanya loyalitas pelanggan, menjadi advocator bagi perusahaan terutama ketika reputasi perusahaan atau produk dilecehkan oleh orang lain, serta membentuk rekomendasi positife dari mulut ke mulut yang sangat menguntungkan bagi perusahaan.

\section{KESIMPULAN DAN SARAN}

\section{Kesimpulan}

Kualitas pelayanan tidak memiliki pengaruh signifikan terhadap kepuasan pelanggan pengguna transportasi online Gojek di kota Jambi dan variabel ini memiliki arah pengaruh yang positif terhadap kepuasan pelanggan.

Persepsi harga memiliki pengaruh signifikan terhadap kepuasan pelanggan pengguna transportasi online Gojek di kota Jambi dan variabel ini memiliki arah pengaruh yang positif terhadap kepuasan pelanggan.

Kualitas pelayanan dan persepsi harga secara bersama-sama memiliki pengaruh signifikan terhadap kepuasan pelanggan pengguna transportasi online Gojek di kota Jambi dan variabel ini memiliki arah pengaruh yang positif terhadap kepuasan pelanggan.

\section{Saran}

Variabel harga merupakan variabel yang paling berpengaruh terhadap kepuasan pelanggan dalam penelitian ini. Diharapkan kedepannya pihak perusahaan Gojek Indonesia mampu menjaga dan meningkatkan persepsi harga terutama pada indikator kesesuaian harga terhadap pelayanan yang diberikan kepada pelanggan, dikarenakan indikator tersebut mendapatkan nilai paling rendah dibandingkan indikator lain dalam variabel persepsi harga. Harga yang sesuai akan meningkatkan kepuasan pelanggan sehingga diharapkan mampu menjangkau pelanggan pengguna transportasi online Gojek yang lebih luas.

Penelitian ini perlu dikembangkan lagi guna mengetahui faktor apa saja yang dapat mempengaruhi kepuasan pelanggan pengguna transportasi online di kota Jambi. Kepuasan pelanggan pengguna transportasi online di kota Jambi dapat dipengaruhi oleh faktor lain, oleh karena itu perlu kajian yang lebih komprehensif, guna menjawab faktor 
lain yang mempengaruhi keputusan pembelian diluar dari variabel bebas yang digunakan dalam penelitian ini.

\section{DAFTAR PUSTAKA}

Augusty, F. (2006). Metode penelitian manajemen. Semarang: Badan Penerbit Universitas Diponegoro.

Aunurrahman. (2009). Belajar dan pembelajaran. Bandung: Alfabeta.

Azwar, S. (2006). Reliabilitas dan validitas. Yogyakarta: Pustaka Pelajar. Jurnal Internasional , 1 (1), 49-57.

Buttle, F. (2007). Customer relationship management (manajemen hubungan pelanggan) concept and tools. Malang: Bayumedia Publishing.

Cipta. Arikunto, S. (2006). Prosedur Penelitian Suatu Pendekatan Praktek. Jakarta: PT. Rinka Cipta.

Dahmiri, D., \& Suzana, V. (2016). Pengaruh kualitas pelayanan terhadap kepuasan masyarakat pada Dinas Kependudukan dan Pencatatan Sipil Kabupaten Sarolangun (Studi Pada Mahasiswa Universitas Jambi). Jurnal Manaejemen Terapan dan Keuangan, 5(3).

Gupta, S., \& Zeithaml, V. (2006). Customer metrics and their impact on financial performance. Marketing science, 25(6), 718-739.

Indriawati, P. (2018). Pengaruh kepercayaan diri dan kecerdasan emosional terhadap hasil belajar mahasiswa Universitas Balikpapan. Jurnal Pendidikan Edutama, 5(2), 1-10..

Kotler, P. (2010). Manajemen pemasaran: analisis, perencanaan, implementasi dan kontrol,(terjemahan Hendra Teguh dan Ronny A. Rusli AK). Jakarta: PT. Ikrar Mandiriabadi.

Kusumastuti, F. (2010). Pengaruh harga, atribut produk dan promosi terhadap keputusan pembelian produk telepon seluler Sony Ericsson (Studi Kasus di Kabupaten Temanggung. (Doctoral dissertation, Diponegoro University).

Lailia, N., Suryoko, S., \& Saryadi, S. (2013). Pengaruh kualitas pelayanan, harga dan nilai pelanggan terhadap tujuan pengguna jasa layanan Bengkel Ahass 0002 Semarang Honda Center. Jurnal Ilmu Administrasi Bisnis , 1 (1), 219-226..

Marati, N. C. (2016). Pengaruh kualitas layanan dan harga terhadap kepuasan pelanggan jasa transportasi ojek online (Studi pada konsumen gojek di Surabaya). Jurnal Pendidikan Tata Niaga (JPTN), 4(3)..

Oktarini, R. (2020). Pengaruh kualitas pelayanan dan harga terhadap kepuasan pelanggan pengguna jasa aplikasi gojek di Kota Tangerang. Jurnal Sekretari Universitas Pamulang, 6(2), 248-257..

Supranto, J. (2006). Pengukuran tingkat kepuasan pelanggan untuk menaikkan pangsa pasar. Jakarta: Rineka Cipta.

Tjiptono, F. (2008). Strategi pemasaran. Yogyakarta. Andi Offset.

Utama, P. (2013). Ahmadi, A. (2009). Psikologi umum edisi revisi. Jakarta: Rineka

Zeithaml, VA, Parasuraman, A., Berry, LL, \& Berry, LL (1990). Memberikan layanan berkualitas: menyeimbangkan persepsi dan harapan pelanggan. Simon dan Schuster. 